\title{
TECHNOLOGY FOR INTENSIVE POULTRY PRODUCTION AS A SOURCE OF ODOUR EMISSIONS WITH TIME-VARYING INTENSITY
}

\author{
Radim KUNEŠ*, Petr BARTOŠ, Ivo CELJAK, Zbyněk HAVELKA, Marie ŠíSTKOVÁ, Miloslav ŠOCH \\ University of South Bohemia in České Budějovice, Czech Republic
}

The technology for intensive broiler breeding using deep litter method provides convenient conditions for production of odour substances inside the barn. As a consequence, there are relatively high odour emissions in the breeding area and its surrounding, which has significant impacts on the life quality of both people and animals. The amount of produced emissions increases in time because it is closely related to the amount of poultry droppings accumulated in litter inside the barn. This paper deals with changes in odour intensity depending on time measured since the beginning of broiler fattening. Odour intensity was measured by methods of dynamic olfactometry. The estimated values gradually increased from $45 \mathrm{ou}_{\mathrm{E}} \cdot \mathrm{m}^{-3}$ to the highest value of $259 \mathrm{ou} \cdot \mathrm{m}^{-3}$, which was determined in the final fattening phase (broilers' age 33 days). The calculated odour substances emission values were in range from $0.02 \mathrm{ou}_{\mathrm{E}} \cdot \mathrm{s}^{-1} \cdot \mathrm{bird}^{-1}$ at the beginning of fattening up to $0.10 \mathrm{ou}_{\mathrm{E}} \cdot \mathrm{s}^{-1} \cdot \mathrm{bird}^{-1}$ in the final fattening phase. Odour emissions increased five times during the fattening period.

Keywords: odour emissions; broiler production; olfactometry; environment; air pollution; welfare

The consumption of meat and other animal products has increased in recent decades. Farmers' efforts to meet market demands lead to intensification of livestock production (Gerber et al., 2013; Powers et al., 2005). Thanks to the improvements in breeding technology, a higher number of animals can be housed in the barn at the same time. However, the intensification of livestock production results in increased concentrations of ammonia, odour and dust not only inside the building, where the breed is located, but also in its surroundings, where these undesirable substances are deliberately discharged throughout the ventilation systems (Brouček and Čermák, 2015; Heyden et al., 2015; Janoško and Čery, 2011).

Intensive livestock farming is a stationary anthropogenic source of odour substances. Odour primarily burdens the barn environment, where the health of the nursing people and animals is negatively affected. However, areas close to the breeding premises are also significantly influenced. The most risky areas are considered to be within 500 meters from the breeding hall (Héroux et al., 2004). The whole situation is further complicated by the trend of recent years, namely the construction of new rural settlements in close proximity to breeding halls. People inhabiting these houses frequently complain about the intense odour that accompanies their stay near the breeding premises. The higher odour concentration can cause a higher risk of respiratory diseases, mucosal irritations or nausea (McArthur, 1987; Radon et al., 2001).

Odour substances are produced mainly by biological degradation of droppings at poultry farms, which take place both under aerobic and anaerobic conditions (Hobbs et al., 2004; Jiang and Sands, 2000; Powers, 2002). The amount of produced droppings depends on the age, weight and health of animals.

Droppings accumulated in the deep litter cannot be effectively removed during the breeding batch and their total amount in the breeding hall gragually increases with time. The microclimate conditions inside a barn also change as the animals are growing up and the amount of odour produced is gradually increasing as well (Dunlop et al., 2016; Said et al., 2016; Winkel et al., 2016).

The total emission of odour substances produced from intensive broiler breeding depend on many factors, such as building design, ventilation mode, barn microclimate, breeding technology, climatic conditions, the age and number of housed animals, nutrition, concentration and dust particle size, ethological manifestations of animals and many others (Redding, 2013; Pogran et al., 2009; Xin et al., 2011; Jiang and Sands, 2000; Knížatová et al., 2009). The spread of odour to the environment depends, among others, on weather and topographical conditions.

The aim of this study was to establish the changes in odour emission in dependence on time continuously throughout the whole fattening process and to determine the basic parameters inside the barn that can affect the overall emission production.

\section{Material and methods}

\section{Breeding technology}

The measurements were performed at intensive poultry farming facility located in the Czech Republic. The 
dimensions of the breeding hall were $102 \mathrm{~m} \times 15 \mathrm{~m} \times 3 \mathrm{~m}$. The broiler fattening at the farm took from 35 to 45 days. Broilers were kept on straw deep litter that provides them thermal insulation, absorbs moisture and proposes convenient conditions for their natural self-expression, such as raking (Collett, 2012).

Vacuum tunnel ventilation, consisting of four fans at the shield of the building, ensured air exchange. This arrangement is advantageous as the intake has to pass through the entire hall, where it takes more dust, bacteria, harmful gases and moisture out of the building. The air in the barn was almost continually swirled by the animals themselves and by other movable elements that were installed in the barn (Daghir, 2008). The combination of laminar and turbulent airflow was present in the stable depending on the position in the barn. Control flaps, which draw outside air, were placed on both sides of the building.

\section{Measurement methodology}

Concentrations of odour substances were estimated by dynamic olfactometry (Capelli et al., 2013; Muñoz et al., 2010), which determines the odour intensity on the basis of human smell sensitivity and appropriate statistical methods (Gostelow and Parson, 2000). The device used for this purpose is called olfactometer. It dilutes the measured sample air in ambient odour-neutral air in strictly defined ratios and those samples are consequently evaluated by an eight-member assessing board. The intensity of smell is given in the European odour unit $\left(\mathrm{ou}_{\mathrm{E}}\right)(\mathrm{CEN}, 2003)$.

\section{Sampling methodology}

Samples were taken into a bag made of the material called Nalophan that eliminates the sorption of odour substances on the sampling bag surface - bags were used only once. Samples were taken using a vacuum container (sampler) in order to avoid undesirable contamination by other substances. Samples were taken behind a suction fan that ensured barn ventilation. Five control measurements were performed during a fattening cycle (in the $4^{\text {th }}, 13^{\text {th }}, 19^{\text {th }}, 26^{\text {th }}$ and $33^{\text {rd }}$ day of this period) and each control measurement consisted of three independent samples evaluation. Afterwards, these samples were transferred into the laboratory, where they were evaluated on the olfactometer (the analysis has to be carried out within 30 hours after collection (CEN, 2003)). In order to minimise the negative influence on animal behaviour, which is affected by regular day-by-day activities (Bockreis and Steinberg, 2005; CEN, 2003), the samples were taken always at the same time between $9 \mathrm{am}$ and $11 \mathrm{am}$. The time necessary for a sample collection was approximately 3 minutes.

\section{Odour samples processing}

The samples were evaluated in laboratory by means of the device Olfactometer TO8-8 (producer ECOMA GmbH, Havighorster Weg 12, D-24211 Honigsee, Germany) that doses the samples diluted in ambient air in given concentrations to the team of eight respondents. At the beginning of the measurement, all respondents undergo a calibration test with reference gas ( $n$-butanol) in order to verify their olfactory sensitivity, which has to be within the required limits. Inappropriate members do not participate in the measurement and are replaced by other respondents.

Samples diluted with various, but strictly given, concentrations in the ambient air are assessed by eight respondents. Samples can be submitted either with increasing or randomly changing concentration. The operator is obliged to include at least one blank sample (a neutral gas sample) in each dilution series. If more than $20 \%$ of these blank samples are positively scored by the reviewer, he is excluded from the assessing board. Each respondent decides whether or not he perceives the tested sample (response YES/NO). The lowest perceived concentration of the diluted sample positively responded by the assessor is called the personal detection limit. When this value is obtained independently from four and more members of the board, it is considered to be a result of the measurement and it is denoted as odour concentration $c_{\text {od }}$. The established values are placed into a standardised measurement protocol, including measurement conditions.

In general, sample assessment is undemanding. Unfortunately, the measurement is a very time-consuming activity because at least three various samples of gas were taken from one odour source and each of them was subjected to three repeated measurements. Therefore, a minimum of nine successful measurements and a minimum of one calibration test have to be performed by each of the eight members of the assessing board in order to determine the exact value of odour concentration (CEN, 2003).

\section{Methodology of calculation of specific emission}

Equations published by Celjak et al. (2016) were used for subsequent calculation and interpretation of results. The emission flow of odour substances $E_{t}$ (in units $\mathrm{ou}_{\mathrm{E}} \cdot \mathrm{s}^{-1}$ ) was calculated according to the following equation:

$$
E_{t}=c_{o d} \cdot Q_{v}
$$

where:

$C_{\text {od }} \quad$ - denotes the odour concentration $\left(\mathrm{ou}_{\mathrm{E}} \cdot \mathrm{m}^{-3}\right)$

$Q_{v} \quad$ - the volume of air removed from the hall by the fan per unit of time $\left(\mathrm{m}^{3} \cdot \mathrm{s}^{-1}\right)$

Specific emission production $E_{k s}$ (in units $\mathrm{ou}_{\mathrm{E}} \cdot \mathrm{s}^{-1} \cdot \mathrm{bird}^{-1}$ ) was calculated according to the equation:

$$
E_{k s}=E_{t} \cdot N^{-1}
$$

where:

- the quantity $N$ denotes the number of animals housed in the breeding hall

\section{Climate monitoring in the barn}

The ventilation of breeding hall, the indoor barn parameters, the outdoor climate (temperature, humidity and other) and the age, weight and number of poultry kept in the barn, were also monitored for the appropriate interpretation of estimated data. Outdoor climate conditions and the rate of fan rotation were measured ambulatory by instruments of the BAT (Best Available Technique) Centre of the University of South Bohemia (CometSystem, Anemometer TESTO and LCA301, weather station DAVIS 6162C and others). Indoor 
Table 1 Microclimatic conditions and information on the housed broilers

\begin{tabular}{|c|c|c|c|c|c|}
\hline Measurement number & 1 & 2 & 3 & 4 & 5 \\
\hline Animals age (day) & 4 & 13 & 19 & 26 & 33 \\
\hline Average weight (g) & 111 & 407 & 720 & 1,300 & 1,754 \\
\hline Indoor temperature $\left({ }^{\circ} \mathrm{C}\right)$ & 32.3 & 28 & 27.4 & 24.6 & 24.5 \\
\hline Outdoor temperature $\left({ }^{\circ} \mathrm{C}\right)$ & 24.2 & 23.7 & 14 & 18.9 & 19.3 \\
\hline Relative indoor humidity (\%) & 59 & 45 & 58 & 68 & 68 \\
\hline Relative outdoor humidity (\%) & 45.6 & 44.9 & 59.3 & 46.6 & 48 \\
\hline Exhaust air from the hall $\left(\mathrm{m}^{3} \cdot \mathrm{s}^{-1}\right)$ & 11.1 & 11.8 & 11.1 & 10.9 & 11.1 \\
\hline Odorous substances concentration $\left(\mathrm{ou}_{\mathrm{E}} \cdot \mathrm{m}^{-3}\right)$ & 45 & 135 & 152 & 100 & 259 \\
\hline
\end{tabular}

Table 2 Emission of odour substances related to various characteristics of the stable

\begin{tabular}{|c|c|c|c|}
\hline Animal age & & of odour sul & \\
\hline day & ou $_{E} \cdot \mathbf{s}^{-1} \cdot$ bird $^{-1}$ & $o u_{E} \cdot s^{-1} \cdot A U^{-1}$ & $o u_{E} \cdot s^{-1} \cdot m^{-2}$ \\
\hline 4 & 0.02 & 0.10 & 0.33 \\
\hline 13 & 0.06 & 3.21 & 1.05 \\
\hline 19 & 0.06 & 3.40 & 1.10 \\
\hline 26 & 0.04 & 2.20 & 0.71 \\
\hline 33 & 0.10 & 5.74 & 1.90 \\
\hline
\end{tabular}

Table 3 Values of odour emission from poultry breedings presented in literature

\begin{tabular}{|c|c|c|c|}
\hline & \multicolumn{2}{|c|}{ Emission of odour substances } \\
\hline $\mathbf{o u}_{\mathbf{E}} \cdot \mathbf{s}^{-1} \cdot \mathbf{b i r d}^{-1}$ & $\mathbf{o u}_{\mathbf{E}} \cdot \mathbf{s}^{-1} \cdot \mathbf{A U} \mathbf{u}^{-1}$ & $\mathbf{o u}_{\mathbf{E}} \cdot \mathbf{s}^{-1} \cdot \mathbf{m}^{-2}$ & reference \\
\hline $0.60^{*}$ & - & - & Winkel et al. (2016) \\
\hline $0.44^{*}$ & $95.6^{* *}$ & $6.1^{* *}$ & Navaratnasamy and Feddes (2004) \\
\hline $0.31^{* *}$ & - & $5.2^{* *}$ & Hayes et al. (1997) \\
\hline $1.22^{* *}$ & - & - & Robertson et al. (2006) \\
\hline $0.97^{* *}$ & - & - & Ogink and Koerkamp (2001) \\
\hline $0.06-0.41^{* * *}$ & - & - & Jugowar and Piotrkowski (2012) \\
\hline $0.08-0.32^{* * *}$ & $135-415^{* * *}$ & - & Clarkson and Misselbrook (1991) \\
\hline- & - & - &
\end{tabular}

barn parameters and other supporting pieces of information were provided by the farmer, since the measurement of these values is a well-known and standardised activity.

\section{Results and discussion}

The measurements were performed in April and May 2016. Five control measurements were performed in total during this period to evenly map the entire fattening cycle. Parameters characterising microclimatic conditions were recorded instantaneously, and a variety of information on the housed animals was collected as well (see Table 1). Only one of the four ventilators, having an average suction power of $11.2 \mathrm{~m}^{3} \cdot \mathrm{s}^{-1}$, was always in operation during sampling.
Calculated values of odour substances emission are presented in Table 2. In order to facilitate the comparison of our results with the results presented by other authors, we have related them also to other quantities characterising the intensive breeding - to the number of housed animals (in units $\mathrm{ou}_{\mathrm{E}} \cdot \mathrm{s}^{-1} \cdot \mathrm{bird}^{-1}$ ), the livestock unit (in units $\mathrm{ou}_{\mathrm{E}} \cdot \mathrm{s}^{-1} \cdot \mathrm{AU}^{-1}$, where $1 \mathrm{AU}$ equals $500 \mathrm{~kg}$ ) and the area of the breeding hall (in units $\mathrm{ou}_{\mathrm{E}} \cdot \mathrm{s}^{-1} \cdot \mathrm{m}^{-2}$ ).

Measured values of odour concentration increase from $45 \mathrm{ou}_{\mathrm{E}} \cdot \mathrm{m}^{-3}$ to the highest value of $259 \mathrm{ou}_{\mathrm{E}} \cdot \mathrm{m}^{-3}$, which was observed in the final fattening phase (i.e. broilers were 33 days old). The emission of odour substances (see Table 2) gradually increased from the value of $0.02 \mathrm{ou}_{\mathrm{E}} \cdot \mathrm{s}^{-1} \cdot \mathrm{bird}^{-1}$ to the five times greater value. The deviation from the ascending trend measured for 26-day-old broilers is considered to be a measurement error, but it could be also 
affected by the change in climatic condition inside the barn (see the development of temperature and humidity). For example, similar deflections in measured values were observed by Amon et al. (1997). Better understanding to the influence of temperature, humidity and other parameters characterising the environment inside and outside of the barn on the emission of odorous substances will be a goal of our further research and we will present the results in our other publication.

Selected results presented by other authors are shown in Table 3. However, comparison of the obtained values with the data published by other authors is complicated. Each of the authors uses a different measurement methodology and the odour emissions are related to different breeding parameters, i.e. they are reported in various units (see also Mielcarek and Rzeźnik (2015)). Amon et al. (1997) presented the values relative to the total livestock area $\left(\mathrm{ou}_{\mathrm{E}} \cdot \mathrm{s}^{-1} \cdot \mathrm{m}^{-2}\right)$, Jugowar and Piotrkowski (2012) and Maasikmets et al. (2015) expressed odour emission relative to livestock units $\left(\mathrm{ou}_{\mathrm{E}} \cdot \mathrm{S}^{-1} \cdot \mathrm{AU}^{-1}\right)$, and the majority of others scientists used the dependence on the number of housed animals $\left(\mathrm{ou}_{\mathrm{E}} \cdot \mathrm{s}^{-1} \cdot\right.$ bird $^{-1}$ ) (Hayes et al., 2006; Ogink and Koerkamp, 2001; Winkel et al., 2016 etc.). Related information (the area of breeding hall, the number of housed animals and their weight) are not provided in these publications and the presented values cannot be re-calculated to another format. The standardisation of measurement methodology in the future would make it easier for comparison of measured data between authors.

The values presented by other authors are significantly higher than the values measured by our team (see Table 3), which was probably influenced by the installed breeding technology at measurements site. However, estimated data have the same trend as data obtained by other authors. For example, similar conclusion have been reached by Amon et al. (1997), who also observed the highest values in two measurements performed during the last week of fattening and twice during the penultimate week of fattening.

\section{Conclusion}

The amount of odour substances emitted from poultry kept on deep litter increases with time. It is closely related to the amount of poultry droppings accumulated inside the barn, so the highest values are usually measured during the final phase of breeding. This conclusion should be taken into account in such situations like proposal of new odour emission measurement methodologies or verification of compliance with emission limits.

According to the directive of the European Commission (2015), the range of produced emission should be within the range of 0.032 to $0.700 \mathrm{ou}_{\mathrm{E}} \cdot \mathrm{s}^{-1} \cdot \mathrm{bird}^{-1}$. The values obtained by our measurement are generally at the lower limit.

\section{Acknowledgements}

This paper is based on the results obtained within the frame of the projects GAJU 094/2016/Z supported by the Grant Agency of the University of South Bohemia in České Budějovice, and QJ1530058 supported by the Ministry of Agriculture of the Czech Republic.
Abbreviations:
$c_{o d} \quad$ - concentration of odour substances $\left(\mathrm{ou}_{\mathrm{E}} \cdot \mathrm{m}^{-3}\right)$
$Q_{v} \quad$ - ventilation of the air from the hall $\left(\mathrm{m}^{3} \cdot \mathrm{s}^{-1}\right)$
$E_{t} \quad$ - odour emissions flow $\left(\mathrm{ou}_{\mathrm{E}} \cdot \mathrm{s}^{-1}\right)$
$E_{k s}$ - specific emission production of odour substances $\left(\mathrm{ou}_{\mathrm{E}} \cdot \mathrm{s}^{-1} \cdot \mathrm{bird}^{-1}\right)$
$\mathrm{AU} \quad-$ animal unit $(1 \mathrm{AU}=500 \mathrm{~kg})$

\section{References}

AMON, M. - DOBEIC, M. - SNEATH, R. W. - PHILIPS, V. R. MISSELBROOK, T. H. - PAIN, B. F. 1997. A farm-scale study on the use of clinoptilolite zeolite and De-Odorase ${ }^{\circledR}$ for reducing odour and ammonia emissions from broiler houses. In Bioresource Technology, vol. 61, pp. 229-237.

BOCKREIS, A. - STEINBERG, I. 2005. Measurement of odour with focus on sampling techniques. In Waste Management, vol. 25, pp. 859-863.

BROUČEK, J. - ČERMÁK, B. 2015. Emission of harmful gases from poultry farms and possibilities of their reduction. In Ekológia (Bratislava), vol. 34, no. 1, pp. 89-100.

CAPELLI, L. - SIRONI, S. - DEL ROSSO, R. - GUILLOT, J. M. 2013. Measuring odours in the environment vs. dispersion modelling: A review. In Atmospheric Environment, vol. 79, pp. 731-743.

CELJAK, I. - KUNEŠ, R. - HAVELKA, Z. - BARTOŠ, P. - ŠÍSTKOVÁ, M. 2016. The issue of poultry farms as sources of odour substances. In Náš chov, vol. 10, no. LXXVI, pp. 80-82. (In Czech: Problematika velkochovů drůbeže jako zdrojů pachových látek).

CLARKSON, C. R. - MISSELBROOK, T. H. 1991. Odour emission from broiler chicken. In NIELSEN, V. C. - VOORBURG, J. H. - L'HERMITE, P. Odour and Ammonia Emission from Livestock Farming. London, UK: Elsevier Applied Science, pp. 933-939. ISBN 9781851667178.

CEN EN - 13725. 2003. Air Quality - Determination of Odour Concentration by Dynamic Olfactometry. European Committee for Standardization.

COLLETT, S. R. 2012. Nutrition and wet litter problems in poultry. In Animal Feed Science and Technology, vol. 173, pp. 65-75.

DAGHIR, N. J. 2008. Poultry Production in Hot Climates. Cambridge, Mass: CABI North American Office, pp. 402. ISBN 978-1-84593-417-0. DUNLOP, M. W. - BLACKALL, P. J. - STUETZ, R. M. 2016. Odour emissions from poultry litter - A review litter properties, odour formation and odorant emissions from porous materials. In Journal of Environmental Management, vol. 177, pp. 306-319.

EUROPEAN COMISION, JOINT RESEARCH CENTRE. 2015. Best Avaible Techniques (BAT), Reference Document for the Intensive Rearing of Poultry or Pigs.

GERBER, P. J. - STEINFELD, H. - HENDERSON, B. - MOTTET, A. - OPIO, C. - DIJKMAN, J. - FALCUCCI, A. - TEMPIO, G. 2013. Tackling climate change through livestock - a global assessment of emissions and mitigation opportunities. Rome: Food and Agriculture Organization of the United Nations (FAO), pp. 137. ISBN 978-92-5-107920-1.

GOSTELOW, P. - PARSON, S. A. 2000. Sewage treatment works odour measurement. In Water Science and Technology, vol. 41, pp. 33-40. HEYDEN, C. V. - DEMEYER, P. - VOLCKE, E. I. P. 2015. Mitigating emissions from pig and poultry housing facilities through air scrubbers and biofilters: State-of-the-art and perspectives. In Biosystems Engineering, vol. 143, pp. 74-93.

HAYES, E. T. - CURRAN, T. P. - DODD, V. A. 2006. Odour and ammonia emissions from intensive pig units in Ireland. In Bioresource Technology, vol. 97, pp. 933-939. 
HÉROUX, M. - PAGÉ, T. - GÉLINAS, C. - GUY, C. 2004. Evaluating odour impacts from a landfilling and composting site: involving citizens in the monitoring. In Water Science and Technology, vol. 50, no. 4, pp. 131-137.

HOBBS, P. J. - WEBB, J. - MOTTRAM, T.T. - GRANT, B. - MISSELBROOK, T. M. 2004. Emissions of volatile organic compounds originating from UK livestock agriculture. In Journal of the Science of Food Agriculture, vol. 84, no. 11, pp. 1414-1420.

JANOŠKO, I. - ČERY, M. 2011. Reduction and elimination of animal odorous substances. In Acta Technologica Agriculturae, vol. 14, no. 4, pp. 90-94.

JIANG, J. K. - SANDS, J. R. 2000. Odour and ammonia emission from broiler farms. Sydney, Australia: Rural Industries Research and Development Corporation, 107 pp. ISBN 0642580324.

JUGOWAR, J. L. - PIOTRKOWSKI, M. 2012. Comparison of odour emission from different systems of keeping poultry. In Journal of Research and Applications in Agricultural Engineering, vol. 57, no. 3, pp. 182-185.

KNÍŽATOVÁ, M. - MIHINA, Š. - KARANDUŠOVSKÁ, I. - ORSÁG, J. ŠOTTNÍK, J. 2009. Concentrations and emissions of ammonia and greenhouse gases in broiler chicken housing in summer and their dependence on selected properties of litter. In Acta Technologica Agriculturae, vol. 12, no. 1, pp. 1-4.

MAASIKMETS, M. - TEINEMAA, E. - KAASIK, A. - KIMMEL, V. 2015 Measurement and analysis of ammonia, hydrogen sulphide and odour emissions from the cattle farming in Estonia. In Biosystems Engineering, vol. 139, pp. 48-59.

MCARTHUR, A. J. 1987. Thermal interaction between animal and microclimate a comprehensive model. In Journal of Theoretical Biology, vol. 126, pp. 203-238.

MIELCAREK, P. - RZEŹNIK, W. 2015. Odor emission factors from livestock production. In Polish Journal of Environmental Studies, vol. 24, no. 1, pp. 27-35.

MUÑOZ, R. - SIVRET, E. C. - PARCSI, G. - LEBRERO, R. - WANG, X. SUFFET, I. H. - STUETZ, R. M. 2010. Monitoring techniques for odour abatement assessment. In Water Research, vol. 44, pp. 5129-5149.

NAVARATNASAMY, M. - FEDDES, J. J. R. 2004. Odour emissions from poultry manure/litter and barns. Poultry Industry Council. PIC Project No. 155. Final report.
OGINK, N. W. M. - KOERKAMP, P. W. G. 2001. Comparison of odour emissions from animal housing systems with low ammonia emissions. In Water Science and Technology, vol. 43, pp. 245-252. POGRAN, F. - ŠOTTNÍK, J. - KARANDUŠOVSKÁ, I. - KNIZŽATOVÁ, M. ORSÁG, J. - MIHINA, Š. 2009. Monitoring of differences of ammonia concetrations during winter and summer feeding in broiler housing. In Acta Technologica Agriculturae, vol. 12, no. 1, pp. 26-28. POWERS, W. 2002. Odor mechanisms and mitigation. In National Poultry Waste Management Symposium 2002, Birmingham, Alabama: Auburn University, pp. 11-17.

POWERS, W. J. - ANGEL, C. R. - APPLEGATE, T. J. 2005. Air emissions in poultry production: current challenges and future directions. In Journal of Applied Poultry Research, vol. 14, no. 3, pp. 613-621.

RADON, K. - DANUSER, B. - IVERSEN, M. - JÖRRES, R. - MONSO, E. - OPRAVIL, U. - WEBER, C. - DONHAM, K. J. - NOWAK, D. 2001. Respiratory symptoms in European animal farmers. In Europien Respiratory Journal, vol. 17, no. 4, pp. 747-754.

REDDING, M. R. 2013. Bentonite can decrease ammonia volatilisation losses from poultry litter: laboratory studies. In Animal Production Science, vol. 53, no. 10, pp. 1115-1118.

ROBERTSON, A. P. - HOXEY, R. P. - DEMMERS, T. G. M. - WELCH, S. K. - SNEATH, R. W. - STACEY, K. F. - FOTHERGILL, A. - FILMER, D. - FISCHER, C. 2002. Commercial-scale studies of the effect of broiler-protein intake on aerial pollutant emissions. In Biosystem Engineering, vol. 82, no. 2, pp. 217-225.

SAID, J. - BOĎO, S. - SAADY, T. - GÁLIK, R. - SARDARY, S. - ABBAS, K. 2016. Effect of broiler chickens living conditions on results of fattening. In Agronomy Research, vol. 14, pp. 228-235.

WINKEL, A. - MOSQUERA, J. - AARNIK, A. J. A. - GROOT KOERKAMP, P. W. G. - OGINK, N. W. M. 2016. Evaluation of oil spraying systems and air ionisation systems for abatement of particulate matter emission in commercial poultry houses. In Biosystems Engineering, vol. 150, pp. 104-122.

XIN, H. - GATES, R. S. - GREEN, A. R. - MITLOEHNER, F. M. MOORE, P. A. Jr. - WATHES, C. M. 2011. Environmental impacts and sustainability of egg production systems. In Poultry Science, vol. 90, no. 1 , pp. 263-277. 